\title{
A Atmosfera da Terra
}

\author{
- sua origem, evolução e características actuais
}

Joaquim J. Moura Ramos a

Luís Leitão ${ }^{b}$

Descrevem-se e interpretam-se as características da atmosfera terrestre actual. Analisa-se a forma como a pressão atmosférica varia com a altitude, variação esta que é descrita pela equação barométrica. Distingue-se diferentes regiões da atmosfera consoante a forma como nelas varia a temperatura com a altitude. Estas variações são interpretadas como resultado da observação da luz solar de diferentes comprimentos de onda a diferentes altitudes. A presença de ozono na estratosfera resulta do facto de a sua produção implicar colisões ternárias e, portanto, exigir pressôes não muito baixas e necessitar, por outro lado, de átomos de oxigénio, o que não acontece nas camadas inferiores da atmosfera devido à absorção de elevada energia pelas camadas superiores. A composição química da atmosfera é homogénea na troposfera, na estratosfera e na mesosfera devido ao carácter dominante dos mecanismos de transporte vertical do ar. Acima da altitude de $101 \mathrm{~km}$ (homopausa) a atmosfera torna-se heterogénea. Enunciam-se alguns argumentos que levam a admitir que a atmosfera terrestre se formou como resultado de processos de desgasificação do nosso planeta que tiveram lugar nos período que se seguiram à sua formação. Esses argumentos baseiam-se na análise comparativa da abundância dos gases raros no Sol, em Vénus, na Terra e em Marte. $O$ facto de existirem indícios geológicos que excluem a possibilidade de presença de ferro metálico no manto e na crusta da Terra quando ocorreram os processos de desgasificação sugere que a atmosfera da Terra seria fracamente redutora e essencialmente constituída por azoto, dióxido de carbono e vapor de água. Por outro lado, a análise das rochas antigas sugere a ausência de oxigénio na atmosfera primitiva. $O$ aparecimento deste estará associado ao aparecimento da vida na Terra e em particular ao desenvolvimento da fotossíntese. Com o aumento da concentração em oxigénio deu-se a formaçâo da camada de ozono na estratosfera como resultado de reacções fotoquímicas e este facto veio criar novas condiçôes ambientais à superfície da Terra que possibilitaram novos desenvolvimentos na evoluçâo da vida. Finalmente, analisam-se alguns aspectos da química dos constituintes atmosféricos. Sublinha-se o papel do azoto como diluente do oxigénio atmosférico e inibidor da sua acção oxidante. Referem-se mecanismos possíveis para a destruiçâo do ozono estratosférico e o papel do dióxido de carbono como regularizador térmico através da sua contribuição para o efeito de estufa. Salienta-se o papel de alguns constituintes menores da atmosfera $\left(\mathrm{CO}, \mathrm{SO}_{2}\right.$, óxidos de azoto) na criação de situações de poluição como o smog fotoquímico e as chuvas ácidas.

\section{Introdução}

Vista do espaço interplanetário, a Terra é uma bela esfera azul salpicada de farrapos brancos. Foram os astronautas das missões Apollo quem teve o privilégio de sentir pela primeira vez a emoção resultante da visão desse espectáculo deslumbrante: a imagem da Terra vista do espaço. E não espanta que eles não tenham encontrado outra coisa para dizer a não ser que a Terra era o objecto mais convidativo que eles podiam ver em todo o céu. Com efeito, a imagem da Terra vista da Lua é muito diferente daquela que temos da Lua a partir da Terra, e a diferença reside na atmosfera terrestre. Podemos ter a sensação de que a atmosfera é ilimitada mas, se bem que os gases atmosféricos existam até centenas de quilómetros da superfície, a pressão decai rapidamente desde $760 \mathrm{~mm} \mathrm{Hg}$ ao nível do mar até $1 \mathrm{~mm} \mathrm{Hg}$ a $50 \mathrm{~km}$ de altitude. Noventa por cento da massa da atmosfera encontra-se abaixo da altitude de $16 \mathrm{~km}$, e como o raio da Terra é de $6370 \mathrm{~km}$, a nossa atmosfera não passa de uma estreita camada envolvente, como a fina casca de uma laranja.

E tal como a casca protege o fruto, também a atmosfera protege a vida no seu interior. Se não existisse a atmosfera, a superfície da Terra seria bombardeada por uma radiação letal - raios cósmicos, luz ultravioleta de alta energia. Para além disso essa diáfana camada de gases é responsável pela manutenção do ambiente térmico ameno necessário à vida. Sem ela a superfície da Terra seria alternadamente agredida pelo Sol escaldante do meio dia e pelo frio gélido da noite. Na Lua, devido à ausência de atmosfera, a temperatura pode subir até cerca dos $100^{\circ} \mathrm{C}$ durante o dia lunar e descer durante a noite aos $-150^{\circ} \mathrm{C}$. A atmosfera terrestre não só protege a vida como zela pela sua manutenção. Muitos organismos vivos precisam do oxigénio atmosférico para respirar e as plantas usam o azoto e o dióxido de carbono para produzir compostos que nos servem de alimento.

A nós, seres transitivos com um curto tempo de vida, podernos-á parecer que a composição atmosférica é estável, que não varia no tempo. No entanto, a realidade é bem diferente. A quantidade de ozono, por exemplo, apresenta alterações sazonais e poderá registar variações a mais longo prazo se não forem para tal tomadas medidas ambientais que se impõem. Mas, para além disso, a Terra já se formou há cerca

\footnotetext{
a Departamento de Engenharia Química, Instituto Superior Técnico.

${ }^{\mathrm{b}}$ Professor Efectivo, Escola Secundária Emídio Navarro.
} 
de 4.5 milhares de milhões de anos $\left(4.5 \times 10^{9}\right.$ ano) e a sua superfície, tal como a sua atmosfera, sofreu modificações profundas até à sua situação presente. A atmosfera actual da Terra é radicalmente diferente da que se pensa ter sido a atmosfera após a formação do planeta.

Tentaremos neste capítulo analisar as prinipais características da atmosfera actual e descrever os traços principais da sua evolução até ao seu estado presente; veremos que o domínio dos conhecimentos básicos de química nos permitirá compreender aspectos importantes desta camada de gás que nos envolve.

\section{A atmosfera actual}

\section{A massa da atmosfera}

A atmosfera é constituída por um fluido compressível, o ar, preso à Terra pela força gravítica. Sabemos que um gás, a uma dada pressão $\mathrm{p}$, tende espontaneamente a expandir-se, a não ser que essa tendência seja contrariada por uma força que se oponha. Essa força é exercida pelas paredes do recipiente se o gás estiver num contentor. No caso da atmosfera, é a força gravítica que se opõe à sua expansão e consequente diluição no espaço interestelar. Num dado ponto da atmosfera a pressão iguala a força gravitacional descendente que se exerce em todo o ar contido numa coluna vertical de secção recta unitária situada acima do ponto considerado. Esta igualdade traduz o equilíbrio que impede o gás atmosférico de se expandir, expansão esta que levaria ao desparecimento da atmosfera. Como a força gravitacional é igual ao produto da massa pela aceleração da gravidade, podemos calcular a massa do ar contido na coluna referida e a partir daí calcular a massa da atmosfera.

A pressão média ao nível do mar é de $1.012 \times 10^{5}$ Pascal (1.012 milibar). A aceleração da gravidade tem um valor médio ao nível do mar de $9.80 \mathrm{~m} \mathrm{~s}^{-2}$. A massa, $\mathrm{m}$, da coluna de ar de secção recta $1 \mathrm{~m}^{2}$ é pois dada por

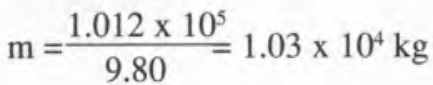

A área da superfície da Terra é de $5.10 \times 10^{14} \mathrm{~m}^{2}$ pelo que a massa total, M, da atmosfera é dada por

$\mathrm{M}=1.03 \times 10^{4} \times 5.10 \times 10^{14}=5.27 \times 10^{18} \mathrm{~kg}$

Este cálculo pode ser feito com um pouco mais de rigor se considerarmos que a superfície da Terra tem zonas com altitudes diferentes. Tendo isso em conta, a pressão média à superfície do planeta é de 984 milibar e o valor da massa da atmosfera assim obtido é de $\mathrm{M}=5.136 \pm 0.007) \times 10^{18} \mathrm{~kg}$.

\section{A equaçāo barométrica}

A pressão atmosférica diminui com a altitude porque o peso da coluna de ar acima do ponto considerado diminui. Podemos calcular a variação da pressão com a altitude considerando a condição atrás referida de equilíbrio hidrostático entre a pressão e a força gravitacional exercida sobre o gás no ponto considerado. A pressão varia com a altitude da seguinte maneira (teorema fundamental da hidrostática):

$\Delta p=-\rho(z) g(z) \Delta z$

em que $\rho(z)$ é a densidade da atmosfera à altura $\mathrm{z}$ e $\mathrm{g}(\mathrm{z})$ a aceleração da gravidade a essa altura. $\mathrm{O}$ sinal - resulta de $\mathrm{p}$ diminuir com z. Para dois pontos a alturas muito próximas teremos $d p=-\rho(z) g(z)$ dz pelo que a variação da pressão com a altitude será dada por

$\frac{d p}{d z}=-\rho(z) g(z)$

Considerando que o gás atmosférico se comporta como um gás perfeito temos $\mathrm{p}=\mathrm{NRT}$ em que $\mathrm{N}$ é a densidade molar do gás (número de moles por unidade de volume) que é dada por $\rho / M$ em que Mé a massa molar média do ar, $R$ a constante dos gases perfeitos e $\mathrm{T}$ a temperatura absoluta. Podemos então escrever

$\frac{\mathrm{dp}}{\mathrm{dz}}=-\left(\frac{\mathrm{Mg}}{\mathrm{RT}}\right) \mathrm{p}=-\frac{\mathrm{p}}{\mathrm{H}}$

em que a quantidade $\mathrm{H}=\mathrm{RT} / \mathrm{Mg}$ tem as dimensões de um comprimento e é designada por escala de altura. Temos então

$$
\frac{\mathrm{dp}}{\mathrm{p}}=-\frac{1}{\mathrm{H}} \mathrm{dz}
$$

A aceleração gravitacional, g, varia inversamente com o quadrado da distância ao centro da Terra. Dado que a espessura da atmosfera é muito pequena comparada com o raio da Terra, podemos considerar que g é constante com a altitude. Então, se g é constante e numa atmosfera isotérmica, $\mathrm{H}$ é constante pelo que a integração da eq. (4) conduz a

$\ln \frac{\mathrm{p}(\mathrm{z})}{\mathrm{p}\left(\mathrm{z}_{\mathrm{o}}\right)}=-\int_{\mathrm{z}_{\mathrm{o}}}^{\mathrm{z}} \frac{1}{\mathrm{H}} \mathrm{dz}=-\frac{1}{\mathrm{H}}\left(\mathrm{z}-\mathrm{z}_{\mathrm{o}}\right)$

ou

$\mathrm{p}(\mathrm{z})=\mathrm{p}\left(\mathrm{z}_{\mathrm{o}}\right) \exp \left[-\frac{\left(\mathrm{z}-\mathrm{z}_{\mathrm{o}}\right)}{\mathrm{H}}\right]$

que é a chamada equação barométrica. Ela mostra que a pressão atmosférica numa atmosfera isotérmica decresce exponencialmente com a altitude e que numa atmosfera não isotérmica a velocidade com que p varia com a altitude é grande se a temperatura for baixa e relativamente pequena se a temperatura for elevada. Se $\mathrm{H}$ for função da altitude, a integração da equação (1) terá de ser feita analítica ou numericamente mas, mesmo assim, a variação da pressão com a altitude será ainda aproximadamente exponencial. Esta conclusão reforça a afirmação que foi feita na introdução segundo a qual a pressão varia muito rapidamente com a altitude e que, portanto, a atmosfera é uma camada gasosa de pequena espessura.

\section{A estrutura térmica da atmosfera}

A atmosfera divide-se em regiões em que a temperatura ora cresce ora decresce com a altitude (ver Figura 1). Até ao princípio deste século pensava-se que a temperatura decres- 
cia sempre com a altitude até atingir o zero absoluto nos limites do espaço intersideral. Com efeito, perto da superfície a temperatura decresce com a altitude como todos sabemos. Mas em 1902 o meteorologista francês de Bort descobriu, depois de inúmeras investigações com balões, que a cerca de $10 \mathrm{~km}$ de altitude a temperatura se tornava constante e aproximadamente igual a $220 \mathrm{~K}$. Chama-se troposfera à região inferior da atmosfera (cerda de $10 \mathrm{~km}$ ) em que a temperatura diminui com a altitude e chama-se tropopausa à região seguinte em que ela se torna constante. A maiores altitudes a temperatura cresce para atingir um máximo de $280 \mathrm{~K}$ a cerca de $50 \mathrm{~km}$. Esta região é designada por estratosfera. Acima de $50 \mathrm{~km}$ a temperatura volta a decrescer com a altitude. Esta região é a mesosfera e a transição entre a estratosfera e a mesosfera em que a temperatura permanece constante é a estratopausa. A cerca de $80 \mathrm{~km}$ a temperatura deixa de decrescer e passa novamente a aumentar. Esta região é a termosfera e a zona de transição entre a mesosfera e a termosfera é a mesopausa.

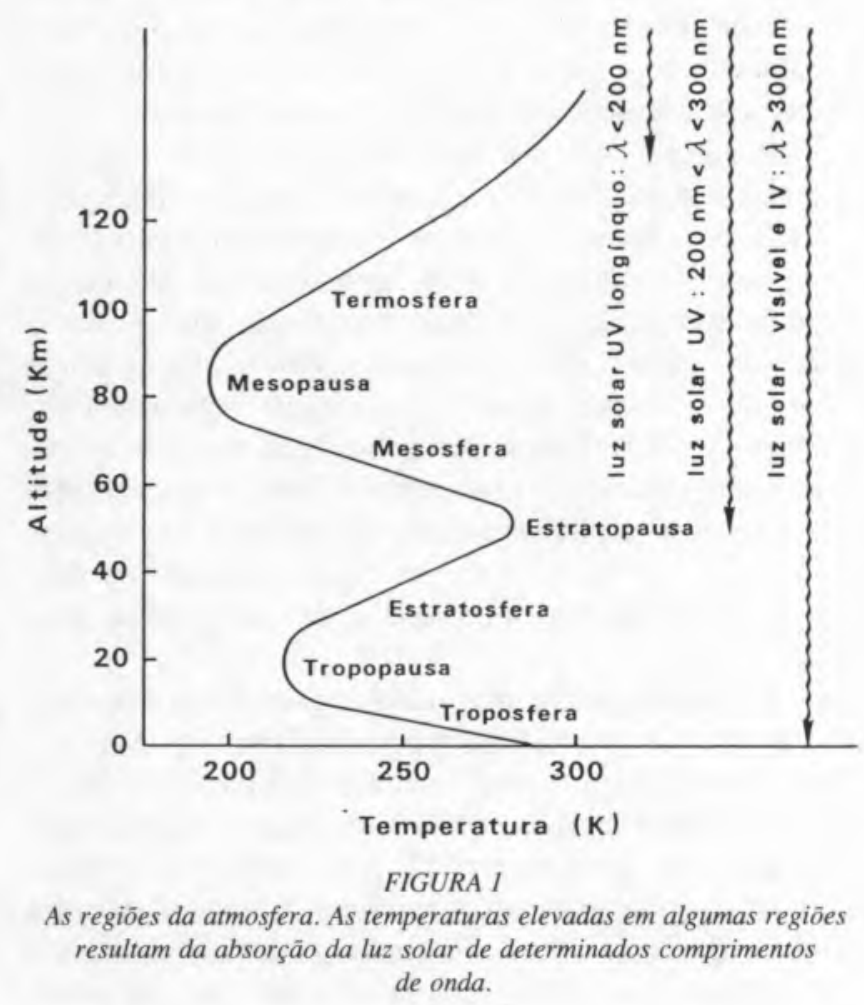

A existência destes aumentos e diminuições alternadas de temperatura são consequência do aquecimento provocado pela absorção da luz de diferentes comprimentos de onda a diferentes altitudes (ver Figura 1). A maior parte da energia que incide sobre a Terra proveniente do espaço é a luz solar nas zonas do visível e do infravermelho próximo (ver espectro da luz solar na Figura 2). Os gases atmosféricos são transparentes a esse tipo de radiação pelo que ela só é absorvida quando atinge a superfície; a maior parte da luz solar é absorvida pela superfície aquecendo-a. Este calor é irradiado para as camadas inferiores da atmosfera tornandoas mais quentes e este efeito vai sendo menos sentido em camadas atmosféricas sucessivamente mais afastadas da superfície: daí o arrefecimento da troposfera à medida que a altitude aumenta.

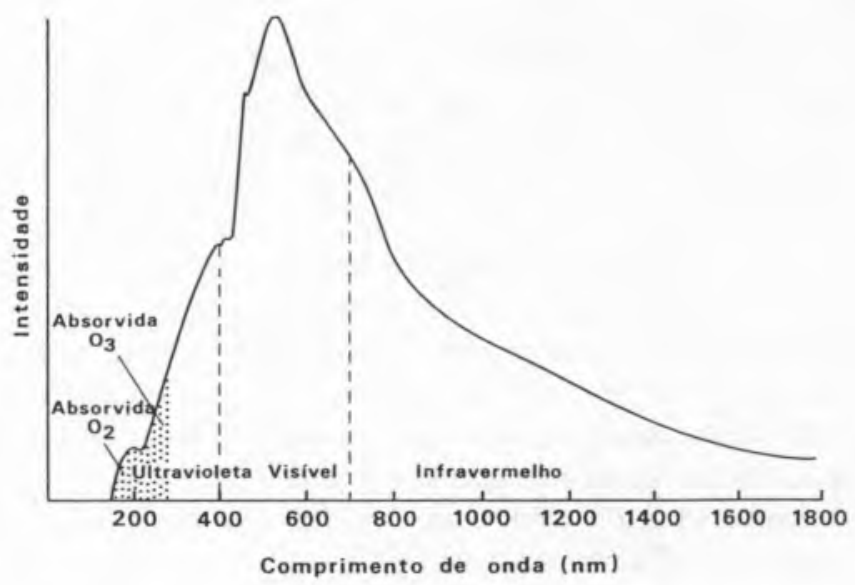

FIGURA 2

$O$ espectro da luz solar. A radiaçâo de comprimento de onda inferior a $200 \mathrm{~nm}$ é absorvida pelo $\mathrm{O}_{2}$ na termosfera. A radiaçāo ultravioleta entre $200 \mathrm{~nm}$ e $300 \mathrm{~nm}$ é absorvida pelo $O_{3}$ na estratosfera.

A radiação ultravioleta tem comprimentos de onda que vão dos $400 \mathrm{~nm}$ (4000 A), logo abaixo da extremidade violeta do espectro visível, até comprimentos de onda muito baixos (20 $\mathrm{nm}$ ). Esta radiação não chega toda à superfície porque parte dela é absorvida pelos gases atmosféricos. A radiação com comprimentos de onda $200 \mathrm{~nm}>\lambda>300 \mathrm{~nm}$ é absorvida pelo ozono, $\mathrm{O}_{3}$, e o máximo de absorção ocorre a $50 \mathrm{~km}$ que é o limite superior da estratosfera. Mas porque razão o ozono se encontra sobretudo a esta altitude? Para compreendermos isto temos de saber que o ozono se forma através da reacção

$\mathrm{O}_{2}(\mathrm{~g})+\mathrm{O}(\mathrm{g})+\mathrm{M}(\mathrm{g}) \Rightarrow \mathrm{O}_{3}(\mathrm{~g})+\mathrm{M}^{*}(\mathrm{~g})$

Em que $\mathrm{O}_{2}(\mathrm{~g})$ é o oxigénio molecular atmosférico, $\mathrm{O}(\mathrm{g})$ é o oxigénio atómico que, como veremos, se forma nas camadas superiores da atmosfera devido à dissociação do $\mathrm{O}_{2}$ pela radiação mais energética proveniente do Sol e $\mathrm{M}(\mathrm{g})$ é uma molécula qualquer $\left(\mathrm{N}_{2}\right.$ ou $\mathrm{O}_{2}$ por exemplo) que tem como função captar a energia libertada dando origem à molécula excitada $\mathbf{M}^{*}(\mathrm{~g})$. Se essa energia não for captada, a molécula de ozono dissocia-se imediatamente $\mathrm{em}_{2}$ e O. Para que o ozono se forme é pois necessária uma colisão reactiva envolvendo três espécies (colisão ternária). A frequência de colisões binárias num gás decresce com a pressão, ou seja, é tanto menor quanto mais rarefeito for o gás. As colisões ternárias são menos frequentes que as binárias e a sua frequência também diminui quando a pressão diminui. $\mathrm{O}$ gás da termosfera é muito rarefeito (como vimos através da equação barométrica, a pressão diminui fortemente com a altitude) e a probabilidade de, nessas condições, ocorrerem colisões ternárias é muito reduzida. Só quando a concentração das moléculas (a pressão) se torna suficientemente elevada às altitudes mais baixas da estratosfera é que o ozono se pode formar em quantidades significativas. Abaixo da estratosfera, por outro lado, a concentração de átomos de oxigénio já é muito baixa dado que a radiação solar de alta energia (ultravioleta longínquo) que as produz a partir da dissociação de $\mathrm{O}_{2}$ já aí não chega pois for absorvida nas camadas superiores da termosfera e da estratosfera. $\mathrm{Na}$ baixa estratosfera e na troposfera não há portanto formação significativa de ozono. É a energia depositada na atmosfera pela radiação 
solar do ultravioleta próximo $(200 \mathrm{~nm}$ a $300 \mathrm{~nm}$ ) que causa um máximo de temperatura na estratopausa. À medida que se desce em altitude a quantidade dessa radiação vai sendo cada vez menor devido à absorção pelo ozono, pelo que a temperatura baixa. $\mathrm{O}$ ozono da estratosfera absorve toda a radiação solar ultravioleta entre $200 \mathrm{~nm}$ e $300 \mathrm{~nm}$ e no entanto a quantidade de ozono aí presente é muito reduzida. É corrente exprimir a quantidade de ozono na estratosfera em termos da espessura da camada de ozono que cobriria a Terra se ele estivesse sob a forma de um gás puro a $0^{\circ} \mathrm{C}$ e a $1 \mathrm{~atm}$. Essa espessura de ozono varia com a latitude e com as estações do ano mas em média é de apenas cerca de $3 \mathrm{~mm}$.

A temperatura da termosfera, tal como acontecia com a estratosfera, também aumenta com a altitude. Isso deve-se ao facto de a radiação mais energética proveniente do Sol (a do ultravioleta longínquo $\operatorname{com} \lambda<200 \mathrm{~nm}$ ) ser absorvida pelo oxigénio molecular, $\mathrm{O}_{2}$, que é dissociado de acordo com a equação

$$
\mathrm{O}_{2}(\mathrm{~g}) \stackrel{\text { hv }}{\Rightarrow} \mathrm{O}(\mathrm{g})+\mathrm{O}(\mathrm{g})
$$

Esta dissociação do oxigénio tem dois efeitos. Em primeiro lugar conduz a uma concentração relativamente elevada de átomos de oxigénio (que vão, como vimos, ter papel importante na formação do ozono estratosférico). Com efeito, acima de $100 \mathrm{~km}$ de altitude a concentração de átomos de oxigénio é superior à concentração de moléculas $\mathrm{O}_{2}$. Em segundo lugar a energia fornecida pela radiação aos átomos de oxigénio traduz-se em calor. À medida que a luz solar passa para camadas inferiores da termosfera menos radiação ultravioleta está disponível e menor é o efeito de aquecimento. A consequência disto é o mínimo de temperatura observada na mesopausa. Em conclusão, toda a radiação solar $\lambda<300 \mathrm{~nm}$ é absorvida antes de atingir a superfície da Terra. E isso tem uma importância vital para as formas de vida expostas à radição solar porque a radiação ultravioleta de alta energia destrói, entre outras coisas, o ADN, o código genético da vida.

\section{A composiçāo da atmosfera}

Os gases atmosféricos estão submetidos a solicitações de vários tipos que fazem com que a atmosfera não seja necessariamente uma mistura gasosa homogénea em todas as suas regiões, isto é que a composição da atmosfera varie com a altitude. Vamos agora tentar descrever as diferentes solicitações a que os constituintes atmosféricos estão sujeitos e tentar compreender, de um ponto de vista qualitativo, como varia com a altitude a composição da atmosfera.

Uma das solicitações é como vimos a do campo gravítico que actua mais fortemente sobre as moléculas mais pesadas. A equação barométrica pode ser escrita para cada constituinte do ar assumindo a forma

$\mathrm{p}_{\mathrm{i}}(\mathrm{z})=\mathrm{p}_{\mathrm{i}}\left(\mathrm{z}_{\mathrm{o}}\right) \exp \left[-\int_{\mathrm{z}_{\mathrm{o}}}^{\mathrm{z}} \frac{1}{\mathrm{H}_{\mathrm{i}}} \mathrm{dz}\right]$

em que $\mathrm{p}_{\mathrm{i}}$ é a pressão parcial do constituinte $\mathrm{i}, \mathrm{H}_{\mathrm{i}}=\mathrm{RT} / \mathrm{M}_{\mathrm{i}} \mathrm{g}$

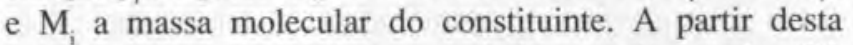
equação vemos que para os constituintes mais pesados $\left(M_{i}\right.$ maior) a pressão parcial varia mais rapidamente com a altitude ao passo que o contrário se verifica para os constituintes mais leves. Este factor tende pois a fazer com que os constituintes mais pesados se tornem menos abundantes que os mais leves a elevada altitude, Imaginemos agora uma atmosfera completamente homogénea em que cessavam todas as turbulências e que ficava apenas sujeita à acção da gravidade. Ao longo do tempo a força gravítica redistribuiria os constituintes da atmosfera da forma atrás descrita, com os constituintes mais pesados essencialmente nas regiões mais baixas da atmosfera e os mais leves mais uniformemente espalhados em altitude. Haveria pois uma difusão dos constituintes até que se realizasse uma distribuição que obedecesse à equação (9). Nestas condições, diz-se que ą atmosfera estaria num estado de equilíbrio difuso. Este processo de difusão sob a acção do campo gravítico demora um certo tempo, isto é, tem um tempo característico chamado tempo de difusâo que à superfície toma o valor $3 \times 10^{12} \mathrm{~s}\left(10^{5}\right.$ ano $)$ que mostra que se trata de um processo lento.

Outra solicitação a que estão submetidos os constituintes da atmosfera está relacionada com as instabilidades desta que têm a ver com a variação da temperatura com a altitude. Imaginemos uma porção de ar que, devido a uma perturbação aleatória, é transportada para uma altitude superior. Se a referida parcela de ar for mais densa que a atmosfera circundante à nova altitude, ela terá tendência a voltar à posição inicial e dizemos então que a atmosfera é estável, isto é, que o movimento vertical das camadas de gás está inibido e que as moléculas individuais do gás sãos transportadas lentamente de uma altitude para outra. Pelo contrário, se o ar da porção deslocada for menos denso que a atmosfera circundante, ele terá tendência a subir ainda mais. A atmosfera é então instável, o movimento vertical das camadas de ar ocorre espontaneamente (fenómenos designados por convexão livre) e existe um rápido processo de mistura dos constituintes atmosféricos de uma altitude para outra.

Quando a nossa porção imaginária de gás sobe na atmosfera ela assume, em cada instante, a pressão da atmosfera circundante. Pelo contrário, a temperatura no seio da porção de gás pode ser diferente da temperatura do meio circundante na medida em que a transferência de calor entre porções de gás é um processo lento devido à baixa condutibilidade térmica genérica dos gases (estes processos podem, em primeira aproximação, ser considerados adiabáticos). Ora, segundo a equação de estado dos gases perfeitos, a densidade varia inversamente com a temperatura (a pressão constante) pelo que a densidade da porção de gás será maior ou menor que a do meio circundante consoante a temperatura da porção for menor ou maior que a daquele. Por isso a estabilidade da atmosfera depende da forma como a temperatura varia com a altitude.

Ao subir na atmosfera, a porção imaginária de gás desloca-se para camadas de menor pressão e portanto expande-se e arrefece. Se nessa região atmosférica a temperatura aumentar com a altitude, a diferença de densidade entre a porção considerada e o meio circundante será acentuada e a porção de gás tenderá a descer novamente: essa região atmosférica será estável. Pelo contrário se a temperatura da atmosfera diminuir com a altitude mais rapidamente do que a temperatura da porção imaginária de gás, então a densidade desta 
será menor que a do meio circundante e haverá convexão livre.

Na troposfera a temperatura decresce acentuadamente com a altitude pelo que o ar circula verticalmente com relativa liberdade. Isso significa que os poluentes gasosos produzidos à superfície da Terra se dispersam facilmente para os níveis mais altos da troposfera. Por vezes, em situações climáticas muito específicas, ocorre um fenómeno chamado inversão em que a temperatura aumenta localmente com a altitude. Nesta situação o movimento vertical do ar é fortemente inibido e os poluentes são retidos junto à superfície. São estas situações que geram as crises mais graves de poluição atmosférica.

$\mathrm{Na}$ estratosfera e na termosfera a temperatura aumenta com a altitude pelo que estas regiões são estáveis. A mistura do ar de uma camada com o de uma outra é lenta. Na mesosfera a mistura vertical é relativamente rápida.

Estes mecanismos de mistura, de transporte vertical do ar, têm, como o mecanismo de difusão, um tempo característico próprio chamado tempo de mistura. O tempo de mistura é curto na troposfera e na mesosfera e relativamente longo na estratosfera e na termosfera. Como o tempo de difusão na troposfera é muito superior ao tempo de mistura podemos concluir que os mecanismos de mistura são mais importantes do que os de separação gravitacional na determinação da variação da composição com a altitude na troposfera. Por outro lado, apesar de o tempo de difusão ser proporcional à densidade da atmosfera e portanto decrescer exponencialmente com a altitude na estratosfera e na mesosfera, os mecanismos de separação gravitacional continuam a ser desprezáveis face aos mecanismos de mistura. Nestas regiões da atmosfera o ar é essencialmente homogéneo ou seja a composição não varia significativamente com a altitude. Na termosfera o tempo de mistura é longo porque a temperatura aumenta com a altitude e o tempo de difusão é relativa-

TABELA 1 - Composiçāo da atmosfera

\begin{tabular}{|c|c|c|c|}
\hline & $\begin{array}{c}\text { Massa } \\
\text { molecular }\end{array}$ & $\begin{array}{c}\text { \% volúmica } \\
\text { (em ar seco) }\end{array}$ & $\begin{array}{c}\text { Massa total } \\
(\mathrm{g})\end{array}$ \\
\hline $\mathrm{H}_{2} \mathrm{O}$ & 18.01534 & variável & $(0.017 \pm 0.001) \times 10^{21}$ \\
$\mathrm{Ar} \mathrm{seco}$ & 28.9644 & 100.0 & $(5.119 \pm 0.008) \times 10^{21}$ \\
$\mathrm{~N}_{2}$ & 28.0134 & $78.084 \pm 0.004$ & $(3.866 \pm 0.006) \times 10^{21}$ \\
$\mathrm{O}_{2}$ & 31.9988 & $20.948 \pm 0.002$ & $(1.185 \pm 0.002) \times 10^{21}$ \\
$\mathrm{Ar}$ & 39.948 & $0.934 \pm 0.001$ & $(6.59 \pm 0.01) \times 10^{19}$ \\
$\mathrm{CO}_{2}$ & 44.00995 & $0.0315 \pm 0.0010$ & $(2.45 \pm 0.08) \times 10^{18}$ \\
$\mathrm{Ne}^{2}$ & 20.183 & $(1.816 \pm 0.004) \times 10^{-3}$ & $(6.48 \pm 0.02) \times 10^{16}$ \\
$\mathrm{He}_{\mathrm{Kr}}$ & 4.0026 & $(5.24 \pm 0.05) \times 10^{-4}$ & $(3.71 \pm 0.04) \times 10^{15}$ \\
$\mathrm{Xe}_{\mathrm{KH}_{4}}$ & 83.80 & $(1.14 \pm 0.01) \times 10^{-4}$ & $(1.69 \pm 0.02) \times 10^{16}$ \\
$\mathrm{H}_{2}$ & 131.30 & $(8.7 \pm 0.1) \times 10^{-6}$ & $(2.02 \pm 0.02) \times 10^{15}$ \\
$\mathrm{~N}_{2} \mathrm{O}$ & 44.0128 & $\sim 1.5 \times 10^{-4}$ & $\sim 4.3 \times 10^{15}$ \\
$\mathrm{CO}$ & 28.0106 & $\sim 1.2 \times 10^{-5}$ & $\sim 1.8 \times 10^{14}$ \\
$\mathrm{NH}_{3}$ & 17.0306 & $\sim 1 \times 10^{-6}$ & $\sim 2.3 \times 10^{15}$ \\
$\mathrm{NO}_{2}$ & 46.0055 & $\sim 1 \times 10^{-7}$ & $\sim 3 \times 10^{13}$ \\
$\mathrm{SO}_{2}$ & 64.063 & $\sim 2 \times 10^{-8}$ & $\sim 8.1 \times 10^{12}$ \\
$\mathrm{H}_{2} \mathrm{~S}$ & 34.080 & $\sim 2 \times 10^{-8}$ & $\sim 2.3 \times 10^{12}$ \\
$\mathrm{O}_{3}$ & 47.9982 & variável & $\sim 1.2 \times 10^{12}$ \\
& 2.01594 & $\sim 5 \times 10^{-5}$ & $\sim 3.3 \times 10^{15}$ \\
\hline
\end{tabular}

mente curto devido à baixa densidade. Estes dois tempos tornam-se iguais a uma altitude de $101 \mathrm{~km}$. Acima deste nível chamado homopausa a difusão torna-se mais importante que a mistura pelo que a abundância dos diferentes constituintes apresenta uma variação diferente com a altitude. Abaixo da homopausa temos a homosfera, acima temos a heterosfera. Dado que a troposfera é relativamente homogénea e uma vez que contém $80 \%$ da massa da atmosfera podemos considerar que a composição à superfície reflecte razoavelmente a composição global da atmosfera. Esta composição está apresentada na Tabela 1.

\section{A evoluçāo da atmosfera}

\section{A origem das atmosferas planetárias}

Para compreender a origem das atmosferas planetárias é necessário ter uma ideia do processo que conduziu à formação dos próprios planetas. Até hoje não conhecemos outros sistemas planetários para além do nosso Sistema Solar, mas pensa-se que eles serão abundantes no Universo e que o seu processo de formação resulta da contracção, seguida, de colapso de uma nuvem de matéria interestelar. Com efeito, a matéria no espaço interestelar encontra-se distribuída por diversos tipos de «objectos astronómicos», um dos quais são as chamadas nuvens de gás e poeira, que são entidades que se estendem por distâncias imensas e cuja forma e densidade pode ser afectada por ocorrências diversas (como a explosão ou a formação de uma estrela na sua vizinhança, a «colisão» com outras nuvens de matéria, e outros) ${ }^{1}$. A hipótese de que o Sistema Solar se terá formado a partir da contracção de uma nuvem de matéria, a nébula solar, já foi formulada há mais de três séculos por Descartes (1644) tendo sido posteriormente desenvolvida por Kant e Laplace. Um dos métodos mais eficazes para tentar reconstituir a história da sua formação consiste em estudar os seus constituintes mais primitivos, isto é, aquels que menos alterações sofreram ao longo da sua história. É o caso dos asteróides, corpos rochosos ou metálicos que descrevem órbitas em torno do Sol semelhantes às dos planetas e que se concentram entre Marte e Júpiter, e também dos cometas, conglomerados de gelo com fraca densidade que descrevem órbitas a grande distância do Sol. É igualmente o caso de Mercúrio, Lua e de alguns satélites dos planetas gigantes que, por serem destituídos de atmosfera, possuem uma superfície que não foi alterada por chuvas e ventos guardando assim as marcas de tempos muito remotos. Os resultados das diferentes missões espaciais permitiram a recolha de informações que vieram reforçar e tornar mais credível a hipótese nebular. De acordo com esta hipótese uma nuvem de matéria interestelar, a nébula solar, terá sofrido um processo de contracção ao qual se seguiu um processo de colapso sob a acção do seu próprio campo gravítico. Na fase final do processo de colapso a nébula solar primitiva terá assumido, como resultado dos processos dinâmicos que nela ocorreriam, uma forma discóide com movimento próprio de rotação, mais denso no centro e com um

\footnotetext{
' As nuvens de matéria interestelar contêm moléculas e átomos no estado gasoso e também grãos de matéria, a chamada poeira interestelar, que consiste em pequenos agregados de material refractário que contém, à superfície, substâncias voláteis adsorvidas.
} 
acentuado gradiente de temperaturas: temperaturas elevadas no centro e baixas na periferia. As turbulências da nébula protossolar em fase de colapso geram instabilidades gravitacionais que estão na origem da formação do Sol e dos planetas gigantes (Júpiter e Saturno). A composição em hidrogénio e hélio é idêntica para estes três astros (por sua vez idêntica à composição do Universo) o que sugere uma formação simultânea. Ao longo do processo de colapso a temperatura aumenta no centro (compressão da nébula) e o gradiente de temperatura acentua-se. Na região interna da nébula a temperatura é suficientemente elevada para apenas permitir a condensação e a acreção dos materiais mais refractários. Os órgãos formados sobretudo por material refractário agregam-se para dar origem a pequenos objectos que capturam, por efeito gravitacional, os objectos mais pequenos à sua volta dando origem aos planetas internos, rochosos. A região mais exterior da nébula solar, mais fria, dá origem à formação dos planetas externos.

Quanto ao centro da nébula protossolar, a pressão e a temperatura são elevadas e vão aumentando com o processo de contracção. Ao serem atingidos determinados valores «críticos» desencadeiam-se as reaç̧ões nucleares (o chamado ciclo protão-protão ou seja a combustão do hidrogénio para dar hélio) e o Sol torna-se uma estrela. Nesta primeira fase o Sol adquiriu uma luminosidade muito intensa e expeliu para o espaço enormes quantidades de matéria e de energia sob a forma daquilo que se designa por vento solar ${ }^{2}$, e que terá dissipado de toda a parte interna do sistema Solar o que ainda restaria do gás da nébula protossolar. Em particular qualquer atmosfera primária ${ }^{3}$ dos planetas internos já formados ou em vias de formação terá sido então dissipada pelo sopro deste vento solar. A observação astronómica de estrelas jovens do tipo do Sol indica que esta fase, designada por T Tauri, é violenta e rápida (dura cerca de $10^{7}-10^{8}$ ano) mas não sabemos ainda exactamente em que fase da formação dos planetas ela ocorreu.

Este cenário para a origem do Sistema Solar é aquele que melhor permite explicar a estrutura e propriedades físicoquímicas dos diferentes planetas. $\mathrm{O}$ problema que agora nos interessa é o de saber como se formaram as atmosferas dos planetas. Em primeiro lugar convém recordar que só pode ter atmosfera um objecto que possua um campo gravítico suficientemente intenso para a reter. Mercúrio, a Lua e a maioria dos satélites conhecidos não têm atmosfera (ou melhor têm atmosferas muito rarefeitas) devido à sua pequena massa. Io, satélite de Júpiter, e Titão, satélite de Saturno, possuem, tal como os restantes planetas, atmosfera. Qual a origem dos gases atmosféricos? Existem quatro fontes capazes de fornecer gases às atmosferas planetárias. Uma delas é o vento solar, mas a contribuição desta fonte para a constituição da atmosfera dos planetas é geralmente considerada de menor

\footnotetext{
${ }^{2} \mathrm{O}$ vento solar é um fluxo de matéria e energia que é emitido pelo Sol (um fluxo desta natureza é também emitido pelas outras estrelas) e que se faz sentir até aos confins do Sistema Solar. Este fluxo terá sido particularmente intenso nos primeiros milhares de anos após a formação do Sol mas ainda se faz sentir actualmente.

${ }^{3}$ Designa-se por primária uma atmosfera formada por gás capturado da nébula no próprio processo de acreção do planeta. Pelo contrário, uma atmosfera secundária é uma atmosfera constituída após a formaç«ao do planeta, quer por libertação de gases do seu interior (actividade vulcânica e geotérmica), quer por contribuições externas ao próprio planeta.
}

importância. Às restantes três fontes correspondem outras tantas teorias, modelos ou hipóteses àcerca da formação das atmosferas consoante a ênfase dada a cada uma delas:

1) a hipótese da liberrtação gasosa a partir do interior do planeta. Segundo esta hipótese os planetas formaram-se por agregação dos grãos de poeira da nébula, grãos esses que continham ainda alguma matéria volátil que terá sido posteriormente libertada em processos de aquecimento associados à evolução do planeta;

2) a hipótese da fonte externa segundo a qual a atmosfera resultaria do bombardeamento do planeta por objectos exteriores ricos em substâncias voláteis (cometas e meteoritos). Este bombardeamento teria sido particularmente intenso nas primeiras centenas de milhar de anos após a formação do planeta e dele restam marcas evidentes nas superfícies de Mercúrio e da Lua;

3) a hipótese da atmosfera primária segundo a qual a atmosfera se teria formado por captura hidrodinâmica do gás da nébula primitiva.

\section{A atmosfera da Terra como atmosfera secundária}

Várias observações levam a considerar que a atmosfera da Terra é uma atmosfera secundária (formada a partir da libertação de gases do seu interior) e não uma atmosfera primordial, resíduo do gás da nébula solar retido quando do processo de acreção do planeta. Uma dessas observações resulta da comparação da abundância dos diferentes elementos na Terra e no Sistema Solar, comparação essa apresentada na Tabela 2. As abundâncias são expressas nessa tabela relativamente ao silício (em n. ${ }^{\circ}$ de átomos por 10000 átomos de silício) mas esse critéio de normalização é arbitrário dado que aquilo que interessa analisar são as abundâncias relativas ou seja o quociente das abundâncias.

Da Tabela 2 conclui-se que não existe nenhum elemento que seja mais abundante na Terra do que no Sistema Solar (não

TABELA 2 - Abundância de alguns elementos na Terra e no sistema Solar (abundância definida como razão entre o número de átomos e 10000 átomos de silício)

\begin{tabular}{|c|c|c|c|c|}
\hline & N. atómico & $\begin{array}{c}\text { Terra } \\
(\mathrm{a})\end{array}$ & $\begin{array}{c}\text { Sistema Solar } \\
\text { (b) }\end{array}$ & $\begin{array}{c}\text { Factor de deficiência } \\
\text { log (b/a) }\end{array}$ \\
\hline $\mathrm{H}$ & 1 & 84 & $3.5 \times 10^{8}$ & 6.6 \\
$\mathrm{He}$ & 2 & $3.5 \times 10^{-7}$ & $3.5 \times 10^{7}$ & 14 \\
$\mathrm{C}$ & 6 & 71 & 80000 & 4.0 \\
$\mathrm{~N}$ & 7 & 0.21 & 160000 & 5.9 \\
$\mathrm{O}$ & 8 & 35000 & 220000 & 0.8 \\
$\mathrm{~F}$ & 9 & 2.7 & 90 & 1.5 \\
$\mathrm{Ne}$ & 10 & $1.2 \times 10^{-6}$ & 50000 & 10.6 \\
$\mathrm{Na}$ & 11 & 460 & 462 & 0 \\
$\mathrm{Mg}$ & 12 & 8900 & 8870 & 0 \\
$\mathrm{Al}$ & 13 & 940 & 882 & 0 \\
$\mathrm{Si}$ & 14 & 10000 & 10000 & 0 \\
$\mathrm{P}$ & 15 & 100 & 130 & 0.1 \\
$\mathrm{~S}$ & 16 & 1000 & 3500 & 0.5 \\
$\mathrm{Cl}$ & 17 & 32 & 170 & 0.7 \\
$\mathrm{Ar}$ & 18 & $5.9 \times 10^{-4}$ & 1200 & 6.3 \\
$\mathrm{Kr}$ & 36 & $6 \times 10^{-8}$ & 0.87 & 7.2 \\
$\mathrm{Xe}$ & 54 & $5 \times 10^{-9}$ & 0.015 & 6.5 \\
\hline
\end{tabular}


há valores de log b/a negativos ou de b/a inferiores a 1). Por outro lado a tabela revela a existência de um grupo de elementos que são tão abundantes na Terra como no Sistema Solar. Esses elementos de que fazem parte o $\mathrm{Si}, \mathrm{Mg}$ e $\mathrm{Al}$ são chamados elementos refractários pois formam compostos que só se volatilizam a temperaturas muito elevadas. Outros elementos, de que fazem parte o carbono e o hidrogénio, formam compostos que são geralmente gasosos a temperaturas relativamente baixas e são chamados elementos voláteis. A tabela mostra que a abundância destes elementos é menor na Terra do que no Sistema Solar, isto é, que existe uma deplecção deste elementos na Terra. Esta deplecção é particularmente acentuada no caso dos gases raros $\mathrm{He}, \mathrm{Ne}, \mathrm{Kr}$ e Xe que são elementos que condensam apenas a muito baixa temperatura e que não têm grande tendência a formar compostos. A deplecção dos gases raros na Terra sugere que não houve retenção significativa de gases pelo planeta quando da sua formação ou seja a Terra é constituída essencialmente por materiais que eram líquidos ou sólidos às temperaturas que prevaleciam na Terra na época da sua formação. A atmosfera do nosso planeta nunca foi pois, provavelmente, um resíduo remanescente do gás da nébula a partir da qual se condensaram o Sol e os planetas.

O estudo da abundância dos gases nas atmosferas planetárias constitui uma forma interessante de tirar conclusões acerca da sua origem. De facto, os gases raros são, como sabemos, substâncias quimicamente inertes e, por outro lado, são constituídos por átomos demasiado pesados para se escaparem do topo da atmosfera para o espaço exterior. Para além disso, são dificilmente incorporados nas rochas superficiais e nos sedimentos pelo que são gases que permanecem na atmosfera ao longo do tempo sem sofrerem alteração significativa. São por isso constituintes particularmente apropriados para o estudo da origem da atmosfera. Vamos considerar $\mathrm{o}$ neon, $\mathrm{o}$ argon e $\mathrm{o}$ xenon, mas no que se refere ao argon apenas consideraremos os isótopos ${ }^{36} \mathrm{Ar}$ e ${ }^{38} \mathrm{Ar}$ dado que o isótopo ${ }^{40} \mathrm{Ar}$ (que é o mais abundante) resulta do decaimento radioactivo do isótopo 40 do potássio não se tratando portanto de um constituinte primordial. Os dados existentes sobre Vénus provêm das missões soviéticas Venera 11 e 12 e da missão americana Pioneer Venus (1978), os dados relativos a Marte provêm das missões Viking (1976) e estão apresentados na Tabela 3.

Destes dados podemos concluir que abundância absoluta de gases raros primordiais diminui na sequência Vénus, Terra, Marte. À primeira vista este resultado poderia surgir como uma confirmação da hipótese da atmosfera primária na medida em que a captura de gases seria mais eficaz a menores distâncias do Sol, regiões em que a nébula era mais densa (maior pressão). No entanto, se assim fosse, as abundâncias relativas deveriam ser idênticas às do Sol porque planetas e Sol se formaram a partir da mesma nébula. Os dados da Tabela 3 mostram claramente que tal não acontece. Se a atmosfera tivesse resultado do bombardeamento meteorítico e cometário seria de esperar que as abundâncias relativas fossem idênticas para os três planetas uma vez que a fonte seria a mesma. De facto verifica-se que os valores das razões ${ }^{20} \mathrm{Ne} /{ }^{36} \mathrm{Ar}$ são idênticas para os três planetas. No entanto, seria neste caso de esperar que as abundâncias absolutas em Vénus e na Terra fossem semelhantes dado que as probabili-
TABELA 3 - Abundâncias absolutas* de gases raros primordiais e abundâncias relativas

\begin{tabular}{|c|c|c|c|c|c|}
\hline & $\mathrm{Ne}$ & ${ }^{36} \mathrm{Ar}+{ }^{38} \mathrm{Ar}$ & $\mathrm{Kr}$ & ${ }^{20} \mathrm{Ne} /{ }^{66} \mathrm{Ar}$ & ${ }^{84} \mathrm{Kr} /{ }^{36} \mathrm{Ar}$ \\
\hline Vénus & $\sim 4 \times 10^{-10}$ & $\sim 3 \times 10^{-9}$ & $2 \times 10^{-10}$ & $\sim 0.5$ & 0.02 \\
\hline Terra & $1 \times 10^{-11}$ & $4.6 \times 10^{-11}$ & $2.9 \times 10^{-12}$ & 0.5 & 0.036 \\
\hline Marte & $4 \times 10^{-14}$ & $2.2 \times 10^{-13}$ & $\sim 2 \times 10^{-14}$ & 0.5 & 0.03 \\
\hline Sol & $1.7 \times 10^{-3}$ & $1 \times 10^{-4}$ & $9.7 \times 10^{-8}$ & 31 & 0.00027 \\
\hline
\end{tabular}

-Abundância absoluta definida pelo quociente entre a massa total do gás e a massa do astro no seu conjunto.

dades de impacto de corpos exteriores com estes dois planetas terão sido semelhantes (Vénus é um pouco menor que a Terra mas está mais próximo do Sol). A Tabela 3 mostra que tal não se observa.Resta a hipótese segundo a qual a atmosfera se formou por libertação de gases do interior do planeta. Neste contexto, a diminuição das abundâncias absolutas de Vénus para a Terra e desta para Marte resultaria do facto de os grãos de matéria cuja agregação originou estes planetas serem mais ricos em matéria volátil nas regiões interiores da nébula onde a pressão das substâncias voláteis era superior. Esta hipótese é presentemente a mais aceite para explicar a origem das atmosferas planetárias.

A composiçâo dos gases libertados e a atmosfera primitiva da Terra

A composição dos gases libertados pela Terra terá sido determinada pela composição química das camadas exteriores da Terra (actualmente ocupadas pelo manto superior e pela crusta). Em particular o carácter oxidante ou redutor desses gases terá dependido do estado de oxidação do manto superior. O estado de oxidação do manto pode ser, em linhas gerais, caracterizado pela presença ou ausência de ferro metálico (livre). Actualmente o manto superior não contém ferro metálico encontrando-se este totalmente segregado no núcleo e é por isso que os gases libertados pelos vulcões actuais são apenas fracamente redutores contendo mais vapor de água do que hidrogénio e mais dióxido de carbono do que monóxido de carbono. No entanto, se o ferro metálico estivesse mais uniformemente distribuído pela Terra no período em que a desgasificação ocorreu mais intensamente, os gases libertados conteriam muito hidrogénio e a atmosfera original teria sido fortemente redutora.

Existem vários indícios que levam a considerar que nunca houve ferro metálico no manto superior e que, portanto, os gases libertados nunca foram fortemente redutores. Com efeito, se a Terra fosse inicialmente homogénea, ela teria sido fria pois as rochas quentes podem fluir e os processos de difusão sáo facilitados. Essa Terra fria teria sofrido um aquecimento gradual como resultado do decaimento dos elementos radioactivos até que o seu interior se tornasse suficientemente macio para que o ferro iniciasse a sua difusão para o manto. A energia gravitacional libertada nesse processo levaria a um aquecimento adicional, a uma fusão mais extensa e a uma diferenciação mais rápida do núcleo. É possível que a segregação do manto tenha sido um acontecimento catastrófico conduzindo à total fusão da Terra e à 
destruição das rochas superficiais. Mas este processo, a ter ocorrido, terá tido lugar muito cedo na história da Terra. Cálculos certamente muito aproximados baseados na estimativa da energia gravitacional disponível e do conteúdo energético inicial da Terra permitem estabelecer em 200000 anos o limite máximo para tal ocorrência. Recorde-se aqui que a idade da Terra está estimada em 4.5 milhares de milhões de anos $\left(4.5 \times 10^{9}\right.$ anos $)$ e que as rochas sedimentares mais antigas conhecidas à superfície da Terra, as formações de ferro em camadas do maciço de Isua na Gronelância, estão datadas em 3.8 mil milhões de anos. Outras observações como a análise do estado de oxidação (reflectido na razão $\mathrm{Fe}_{2} \mathrm{O}_{3} / \mathrm{FeO}$ ) das rochas do manto superior (rochas ultramáficas e basaltos) sugerem que essas rochas nunca estiveram em contacto com ferro metálico.

Todos estes indícios levam a considerar que a Terra não se formou de forma homogénea, que a segregação do núcleo ocorreu na fase de crescimento do planeta e não depois, que nunca houve ferro metálico no manto superior e que, portanto, os gases libertados pelas camadas exteriores da Terra continham pouco hidrogénio e a atmosfera primitiva nunca terá sido fortemente redutora. Após a diferenciação do manto, a superfície da Terra seria mais quente do que actualmente, com fontes de energia mais intensas resultantes do decaimento de alguns elementos e das fases finais de acreção do planeta. A actividade tectónica e vulcânica seria então mais intensa e a libertação de gases terá diminuído ao longo do tempo. Estima-se que o processo de desgasificação terá sido essencialmente confinado ao primeiro milhar de milhões de anos da História da Terra.

\section{A atmosfera antes da vida}

Os gases mais abundantemente libertados da superfície da Terra seriam pois o vapor de água, o dióxido de carbono e o azoto. $\mathrm{O}$ mesmo terá acontecido nos planetas mais próximos de nós, Vénus e Marte. No entanto, as diferentes distâncias ao Sol (diferentes temperaturas superficiais) levou a uma evolução diferente das atmosferas destes planetas.

No entanto, a composição da atmosfera não é um reflexo directo da composição dos gases vulcânicos devido aos fenómenos de condensação e precipitação, às reacções destes gases com os materiais da superfície, às reacções fotoquímicas (induzidas pela radiação solar). E também devido ao escape dos gases mais leves que se libertam da atmosfera devido à fraca atracção gravítica que sobre eles é exercida. Por exemplo, o hidrogénio é um gás que também é libertado pelos vulcões mas, dado que tem moléculas muito leves, elas têm uma energia cinética elevada ou uma velocidade média elevada. Recordemos que a teoria cinética dos gases nos permite calcular a velocidade média das partículas de um gás através da expressão

$<v>=\sqrt{\frac{3 R T}{M}}$

em que M é a massa molar. Nas camadas superiores da atmosfera (termosfera), em que a temperatura pode atingir 800 a $2000 \mathrm{~K}$, as moléculas mais leves têm velocidades médias elevadas. Ora para que um objecto, seja ele uma molécula ou uma nave espacial, se escape ao campo gravita- cional da Terra, é necessário que ele atinja nas camadas superiores da atmosfera uma velocidade de cerca de 11 $\mathrm{km} \mathrm{s}^{-1}$. Esta velocidade é a chamada velocidade de escape. Ora a velocidade média do hélio $\left(\mathrm{M}=4 \mathrm{~g} \mathrm{~mol}^{-1}\right)$ a $2000 \mathrm{~K}$ é de $3.5 \mathrm{~km} \mathrm{~s}^{-1} \mathrm{e}$ a do hidrogénio molecular cerca de $5 \mathrm{~km} \mathrm{~s}^{-1}$. Estas velocidades são inferiores à velocidade de escape mas lembremos que se trata de velocidades médias. Se recordarmos a distribuição de Maxwell das velocidades de um gás compreenderemos facilmente que muitas moléculas de $\mathrm{H}_{2}$ e átomos de $\mathrm{He}$ terão velocidades superiores e, portanto, condições para se escaparem à atracção gravítica. Isto explica a ausência do $\mathrm{He}$ (um dos elementos mais abundantes no Universo) na atmosfera da Terra. A pequena quantidade de $\mathrm{H}_{2}$ resulta de um equilíbrio entre a produção vulcânica e a tendência para o escape. No que diz respeito ao vapor de água, este é retido pelo campo gravítico e foi portanto sendo acumulado na atmosfera. Quando se atingiu a pressão de saturação, o vapor começou a condensar e um período de chuvas cobriu o planeta dando progressivamente origem aos oceanos. O dióxido de carbono também se foi acumulando na atmosfera, mas o aparecimento de água líquida à superfície do planeta veio introduzir um mecanismo para o retirar da atmosfera. Com efeito, o dióxido de carbono dissolve-se na água o que lhe permite reagir com as rochas para formar os carbonatos das rochas sedimentares. Assim, o dióxido de carbono foi em grande parte retirado da atmosfera para se encontrar nas rochas sedimentares. As rochas da Gronelância (com 3.8 mil milhões de anos) são rochas sedimentares que apresentam camadas de carbonatos e de óxidos de ferro. A formação dessas rochas implica que na época os oceanos já estariam formados. Com a passagem do vapor de água para os oceanos e do dióxido de carbono para os carbonatos, o azoto foi-se acumulando e tornou-se o constituinte mais abundante.

Quanto ao oxigénio, que é um constituinte abundante na atmosfera actual, ele não estaria presente na atmosfera primitiva. Primeiro porque não é um gás expelido pelos vulcões e depois porque mesmo que existisse em pequenas quantidades ele seria destruído fotoquimicamente. Recordemos que as radiações solares de maior energia, em particular as do ultra-violeta longínquo, não atingem actualmente a superfície da Terra porque são absorvidas pela atmosfera e em particular pelo ozono da estratosfera. Na Terra primitiva não havia ozono na estratosfera pelo que o fluxo de radiação solar que atingia a superfície da Terra continha fotões de elevada energia susceptíveis de destruir determinadas moléculas como as de oxigénio.

Além disso existem indícios geológicos que reforçam esta ideia da ausência de oxigénio na atmosfera prebiótica e que se baseiam na grande reactividade do oxigénio molecular. Com efeito, o ferro que encontra nas rochas sedimentares com idade superior a 2 mil milhões de anos é ferro ferroso ou seja Fe (II). É o caso dos depósitos desimentares de urânioouro da África do Sul que contêm pirite (dissulfureto de ferro, $\mathrm{FeS}_{2}$ ). $\mathrm{O}$ ferro (II) destas pirites seria rapidamente oxidado a $\mathrm{Fe}$ (III) pelo oxigénio molecular e não é, portanto, provável que estes sedimentos se tenham formado numa atmosfera oxidante. Outro exemplo é o das chamadas «banded iron formations» (formações de ferro estratificadas) de que são exemplo as rochas de Isua na Gronelândia que já 
referimos. Trata-se de formações sedimentares que contêm camadas alternadas de minerais de ferro e carbonatos. Estas rochas, que resultam da precipitação, a partir dos oceanos, dos minerais que as constituem, apresentam sempre o ferro no seu estado de oxidação (II) e portanto foram formadas em épocas em que a atmosfera da Terra não continha oxigénio. $\mathrm{O}$ facto de nos registos geológicos não aparecerem formações deste tipo mais jovens que 2 mil milhões de anos resulta provavelmente do facto de, há 2 mil milhões de anos para cá, a quantidade crescente de oxigénio da atmosfera ter levado à oxidação do ferro (II) a ferro (III), impedindo assim a formação deste tipo de rochas.

As diferentes condições existentes em Vénus e Marte conduziram a atmosferas diferentes apesar de os gases libertados terem sido provavelmente os mesmos. As temperaturas mais elevadas de Vénus impediram a formação dos oceanos e mantiveram o vapor de água e o dióxido de carbono na atmosfera. As moléculas de água foram rapidamente destruídas pela radiação solar intensa dando origem a uma atmosfera predominantemente constituída por dióxido de carbono. As baixas temperaturas de Marte solidificaram a água e o dióxido de carbono. $\mathrm{O}$ azoto escapou-se para o espaço exterior devido ao fraco campo gravítico do planeta (velocidade de escape baixa). O que ficou foi uma muito ténue atmosfera. As temperaturas da Terra permitiram que o $\mathrm{CO}_{2}$ passasse para as rochas evitando assim uma atmosfera tão densa como a de Vénus e preservaram ao mesmo tempo a presença de água líquida na superfície. A atmosfera fracamente redutora, a água líquida à superfície, as temperaturas amenas, foram condições que possibilitaram o aparecimento de vida na Terra. A evolução posterior da atmosfera foi dominada pela existência dos processos biológicos.

\section{A formaçâo do oxigénio atmosférico}

A evolução da atmosfera é frequentemente dividida em etapas das quais salientamos três. A etapa química é aquela que descrevemos atrás em que a atmosfera da Terra cresceu, até ter aproximadamente a massa que tem hoje, a partir da libertação de gases do seu interior. É a fase pré-biológica em que a composição da atmosfera é governada por processos físicos e químicos que determinaram as condições ambientais nas quais a vida surgiu. A partir do momento em que surgiram os primeiros organismos vivos, os factores biológicos passam a ser aqueles que determinam a composição atmosférica. É a etapa microbiana, em que os organismos desenvolvem gradualmente as suas capacidades metabólicas e a composição da atmosfera evolui como resposta à introdução desses sucessivos tipos de metabolismo. Os tipos de metabolismo dos organismos mais primitivos terão passado por processos de fermentação, respiração anaeróbica, e respiração aeróbica, culminando com o desenvolvimento da fotossíntese das plantas verdes e com o consequente aumento da quantidade de oxigénio atmosférico.

A partir da etapa microbiana, os processos metabólicos não sofreram alterações significativas mas o mesmo não aconteceu com o clima e a distribuição dos continentes, o que modificou as condições de equilíbrio entre os processos de formação e de consumo dos constituintes atmosféricos. Nesta etapa a a atmosfera, evolui não como resultado de factores biológicos, mas devido a factores geológicos que alteram a distribuição dos organismos activos. É a etapa geológica. Não nos interessa aqui analisar em pormenor o que poderá ter acontecido em cada uma destas etapas. Limitar-nos-emos a tentar explicar em traços largos como poderá ter ocorrido a passagem da atmosfera secundária da Terra, moderadamente redutora, à atmosfera fortemente oxidante que temos hoje. A análise das rochas mais antigas e outras evidências geológicas parecem indicar que o oxigénio começou a aparecer na atmosfera há cerca de 2 mil milhões de anos. Parte deste oxigénio poderia resultar da fotólise (dissociação de uma molécula pela luz) do vapor de água:

$2 \mathrm{H}_{2} \mathrm{O}(\mathrm{g}) \stackrel{\text { hv }}{\Rightarrow} 2 \mathrm{H}_{2}(\mathrm{~g})+\mathrm{O}_{2}(\mathrm{~g})$

O hidrogénio formado teria tendência, como vimos, a escapar-se para o espaço exterior e o oxigénio acumular-se-ia na atmosfera. No entanto, este processo não seria suficientemente eficaz para produzir a quantidade de oxigénio que existe actualmente na atmosfera. Por isso, e na ausência de outras fontes de oxigénio plausíveis, pensa-se que a maior parte do oxigénio atmosférico tem uma origem biológica e resulta do aparecimento de determinado tipo de algas que se supõe terem sido os primeiros organismos a utilizar a fotossíntese no seu metabolismo. A fotossíntese é um conjunto de reacções químicas em que as plantas verdes utilizam a energia da luz solar para transformar o dióxido de carbono e a água em moléculas como a glucose que depois são utilizadas pela planta como alimento (como fonte de energia). A transformação pode ser resumida da seguinte maneira:

$$
6 \mathrm{CO}_{2}+6 \mathrm{H}_{2} \mathrm{O} \stackrel{\text { hv }}{\Rightarrow} \mathrm{C}_{6} \mathrm{H}_{12} \mathrm{O}_{6}+6 \mathrm{O}_{2}
$$

O oxigénio molecular é libertado como produto secundário e a energia armazenada na glucose é utilizada pelo organismo quebrando esta molécula em moléculas mais pequenas (recordar que uma reacção de dissociação é um processo exotérmico):

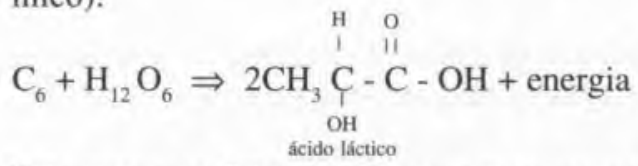

Este processo fotossintético e esteve na origem do lançamento na atmosfera de grandes quantidades de oxigénio e teve importância no desenvolvimento ulterior da vida sobre o planeta. Antes da existência de oxigénio atmosférico havia fortes constrangimentos à evolução da vida dada a violência da radiação solar que atingia a superfície do nosso planeta. Com o aparecimento do oxigénio forma-se a camada de ozono que torna o ambiente da Terra muito mais ameno para os organismos primitivos. Por outro lado, o aumento a pressão parcial de oxigénio na atmosfera veio tornar possível o desenvolvimento de formas de vida com um metabolismo baseado em processos de respiração altamente eficazes do ponto de vista energético. A respiração é um processo químico através do qual os organismos oxidam completamente a glucose e que não é mais do que o processo inverso da fotossíntese:

$\mathrm{C}_{6} \mathrm{H}_{12} \mathrm{O}_{6}+6 \mathrm{O}_{2} \Rightarrow 6 \mathrm{CO}_{2}+6 \mathrm{H}_{2} \mathrm{O}+$ energia 
Os organismos fotossintéticos libertam oxigénio e transformam o carbono inorgânico $\left(\mathrm{CO}_{2}\right)$ em carbono orgânico (glucose). Os organismos que respiram consomem oxigénio da atmosfera e transformam o carbono orgânico em carbono inorgânico. Por outras palavras, as reacções (12) e (14) compensam-se, o que poderia sugerir que não existe um fornecimento efectivo de oxigénio à atmosfera. No entanto isso não é verdade na medida em que parte do carbono orgânico é retido nos sedimentos no fundo dos lagos e mares e nos jazigos fósseis. Esse carbono foi produzido por organismos fotossintéticos (eq. (12)) que libertaram o oxigénio correspondente mas, dado ele estar retido nos sedimentos (não faz parte de organismos vivos), já não pode participar, através da eq. (14), no consumo do oxigénio correspondente. A quantidade deste carbono orgânico retido nos sedimentos é equivalente ao fornecimento efectivo de oxigénio para a atmosfera. Podemos assim fazer uma estimativa da quantidade total de oxigénio que foi lançado na atmosfera. A massa total das rochas sedimentares está estimada em $2 \times 10^{24} \mathrm{~g} \mathrm{e}$ contém uma quantidade de carbono orgânico de cerca de $0,4 \%$. O carbono orgânico retido nos sedimentos é pois de $8 \times 10^{21} \mathrm{~g}$. A partir da reacção (12) vemos que cada átomo de carbono da glucose corresponde a uma molécula de $\mathrm{O}_{2}$ libertada. Portanto terá havido um fornecimento de $2 \times 10^{22} \mathrm{~g}$ de $\mathrm{O}_{2}$ à atmosfera. A maior parte deste oxigénio $\left(1.9 \times 10^{22} \mathrm{~g}\right)$ terá sido consumido na oxidação dos minerais inorgânicos pelo que a quantidade de oxigénio que resta na atmosfera seria de cerca de $10^{21} \mathrm{~g}$.

\section{Alguns aspectos da química dos constituintes do ar}

\section{O oxigénio}

O oxigénio é um elemento abundante em todos os planetas internos e nos seus satélites, mas só na Terra é que ele existe em grande quantidade na atmosfera sob a forma molecular, $\mathrm{O}_{2}$. Isso resulta de duas peculiaridades do nosso planeta: a grande quantidade de água nos oceanos e a abundância da vida.

$\mathrm{Na}$ Terra o oxigénio é de todos os elementos o mais abundante e constitui $48 \%$ da sua camada exterior (crusta terrestre, atmosfera e águas superficiais). Apesar de existir em grande quantidade na atmosfera ( $20 \%$ do seu volume) sob uma forma não combinada, a maior parte do oxigénio existe sob a forma de compostos, sobretudo na crusta terrestre em que está nos óxidos de silício e alumínio (silicatos). Apesar da sua grande abundância no planeta actual, o oxigénio não existia na Terra primitiva; a sua presença deve-se a processos posteriores de fotólise da água (destruição da sua molécula pela radiação) e sobretudo ao desenvolvimento dos processos de fotossíntese. O facto de o oxigénio existir predominantemente sob a forma de compostos resulta do facto de a maioria dos elementos formar óxidos estáveis. Felizmente para a vida, o oxigénio molecular, $\mathrm{O}_{2}$, reage lentamente a temperaturas moderadas devido à elevada energia da ligação oxigénio-oxigénio. Se tal não acontecesse, a combustão de todo o material orgânico ocorreria rapidamente e os organismos vivos não poderiam sobreviver. Mas uma reacção de combustão, uma vez iniciada, liberta uma grande quantidade de calor e isso aumenta a velocidade da reacção (as reacções são muitas vezes mais rápidas a alta temperatura). Um incêndio numa floresta é um bom exemplo do que acontece quando a reacção do $\mathrm{O}_{2}$ com a matéria orgânica se inicia. O oxigénio foi descoberto em 1774 pelo químico sueco K.W. Scheele e pelo químico inglês J. Priestley. Qualquer deles produziu o gás $\mathrm{O}_{2}$ por aquecimento de óxidos, particularmente do óxido de mercúrio

$$
2 \mathrm{HgO}(\mathrm{s}) \stackrel{\Delta}{\Rightarrow} 2 \mathrm{Hg}(\mathrm{l})+\mathrm{O}_{2}(\mathrm{~g})
$$

A sua produção em grande escala faz-se hoje por destilação do ar líquido. $\mathrm{O}$ ar é filtrado para o limpar de partículas de poeira, sendo então comprimido e arrefecido de forma que o vapor de água e o $\mathrm{CO}_{2}$ congelam e separam-se. $\mathrm{O}$ ar comprimido e arrefecido deixa-se então expandir o que provoca o seu arrefecimento $(77 \mathrm{~K})$ e liquefacção. Seguidamente o ar líquido é destilado. $\mathrm{O}$ azoto e o argon são mais voláteis pelo que saem pelo topo da coluna de destilação antes do oxigénio. Este condensa a $90 \mathrm{~K}$ constituindo um líquido magnético azul pálido. O gás é incolor e inodoro. A cor azul do líquido resulta das interacções intermoleculares ou seja da cooperação entre pares de moléculas na absorção da luz.

A estrutura molecular do oxigénio não é convenientemente descrita pela representação de Lewis. Nenhuma das fórmulas

$$
: \ddot{\mathbf{O}}=\ddot{\mathbf{O}}:: \ddot{\mathbf{O}}-\ddot{\mathbf{O}}:
$$$$
\text { (a) (b) }
$$

dá conta das propriedades do oxigénio. De acordo com a fórmula (a) o oxigénio teria uma dupla ligação e seria diamagnético. No entanto o oxigénio molecular é paramagnético. A fórmula (b) revela o paramagnetismo mas descreve a ligação como simples o que não se coaduna com o comprimento da ligação na molécula de $\mathrm{O}_{2}$ que é de $1.21 \AA$ (o comprimento da ligação $\mathrm{O}-\mathrm{O}$ no peróxido de hidrogénio é de $1.49 \AA$ ) sugerindo uma ligação múltipla. Como se sabe a Teoria das Orbitais Moleculares prevê convenientemente o paramagnetismo do oxigénio e a ordem de ligação. Uma das aplicações das propriedades magnéticas do oxigénio consiste na medida da concentração deste gás em atmosferas artificiais como é o caso das incubadoras usadas para crianças prematuras.

A maior parte do oxigénio produzido industrialmente (cerca de $2 / 3$ ) é usado na produção do aço. $\mathrm{O}$ aço que sai de um alto forno contém 3 a $4 \%$ de carbono e é macio e quebradiço. Para torná-lo mais resistente é preciso eliminar parte desse carbono o que se faz por oxidação controlada com $\mathrm{O}_{2}$. Outra utilização importante do oxigénio reside na indústria química, em particular na preparação do óxido de etileno a partir do etileno.

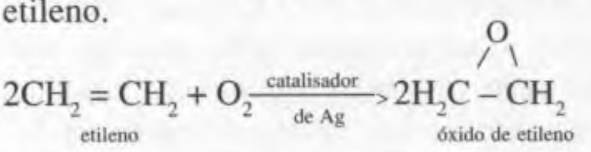

O óxido de etileno serve para sintetizar muitos produtos químicos entre os quais o etilenoglicol, $\mathrm{CH}_{2} \mathrm{OHCH}_{2} \mathrm{OH}$, que é usado como anti-congelante nos automóveis e na síntese de fibras e filmes de poliester.

$\mathrm{O}$ ozono, $\mathrm{O}_{3}$, é uma forma alotrópica do oxigénio (é uma forma estrutural diferente do mesmo elemento). A sua estrutura electrónica pode ser descrita a partir de duas fórmulas de ressonância 
<smiles>O=[O+][O-]</smiles>

que conferem à ligação oxigénio-oxigénio do ozono um carácter parcial de ligação dupla. Este carácter ressalta da comparação do comprimento das ligações no peróxido de hidrogénio (ligação simples, $1.49 \AA$ ), ozono (1.28 $⿱$ ) e oxigénio molecular (ligação dupla, 1.21 Å). O ângulo da ligação O-O-O- é de $117^{\circ}$ o que é próximo do previsto para uma hidridação $\mathrm{sp}^{2}$.

$\mathrm{O}$ ozono puro é um gás azul pálido que condensa a $-180^{\circ} \mathrm{C}$ para formar um líquido azul escuro instável e explosivo. $\mathrm{O}$ sólido também é instável e tem uma cor violeta forte. Em fracas concentrações como as que ocorrem na troposfera ( 0.05 partes por milhão) o ozono tem um cheiro agradável e refrescante. Este cheiro sente-se particularmente em dias de muito Sol ou depois das trovoadas pois o ozono forma-se quando ocorre uma descarga eléctrica em atmosfera de oxigénio. É este aliás o método laboratorial para produzir ozono:

$$
3 \mathrm{O}_{2}(\mathrm{~g}) \underset{\text { eléctrica }}{\stackrel{\text { descarga }}{\Rightarrow}} 2 \mathrm{O}_{3}(\mathrm{~g})
$$

Em dias de elevada poluição atmosférica ou junto de equipamento eléctrico a concentração de ozono pode atingir valores mais elevados ( 0.15 ppm ou mais) e, nessas condições, tem um cheiro irritante, produz dores de cabeça e é venenoso. Nos aviões comerciais que voam a altitudes da ordem dos 15 $\mathrm{km}$ o ozono existente na cabina provocaria tosse e dores no peito e por isso se usam filtros apropriados por onde passa o ar e que decompõem o ozono em oxigénio normal. O ozono também é produzido quando a luz ultravioleta das lâmpadas de estirilização irradia o oxigénio atmosférico. As propriedades germicidas destas lâmpadas são em parte devidas ao ozono. Dado que é muito reactivo (forte agente oxidante), o ozono ataca muitas substâncias orgânicas. Por exemplo, as duplas ligações carbono-carbono da borracha são atacadas provocando a sua degradação. As propriedades branqueantes e germicidas do ozono levam a encarar a possibilidade de ele vir a substituir o cloro na desinfecção das águas.

Mas certamente que o papel mais importante do ozono é a sua presença na estratosfera onde absorve a radiação solar de alta energia que seria letal para os seres vivos caso atingisse a superfície da Terra. Muito se tem falado nos últimos anos no papel nefasto que a actividade humana pode ter na destruição do ozono estratosférico. Estes temores têm de facto razão de ser na medida em que a molécula de ozono é instável decompondo-se facilmente para dar oxigénio, $\mathrm{O}_{2}$. Este processo que é lento em condições normais, pode ser acelerado por determinadas substâncias (catalisadores) fazendo com que a velocidade de decomposição se torne maior do que a velocidade com que o ozono se forma na estratosfera a partir de moléculas e de átomos de oxigénio. Entre as substâncias que se sabe catalisarem a decomposição do ozono contam-se o óxido nítrico e o cloro atómico. $\mathrm{O}$ óxido nítrico pode formar-se a partir do azoto e oxigénio atmosféricos quando submetidos a temperaturas elevadas. Tais condições existem nos gases de exaustão dos aviões supersónicos e daí a polémica gerada há anos quando do lançamento do avião comercial supersónico Concorde. O cloro atómico reage com o ozono através das reacções:

$$
\begin{aligned}
& \mathrm{Cl}+\mathrm{O}_{3} \Rightarrow \mathrm{ClO}+\mathrm{O}_{2} \\
& \mathrm{ClO}+\mathrm{O} \Rightarrow \mathrm{Cl}+\mathrm{O}_{2}
\end{aligned}
$$

A reacção global é então

$\mathrm{O}_{3}+\mathrm{O} \Rightarrow 2 \mathrm{O}_{2}$

o que mostra que os átomos de cloro não são consumidos mas funcionam como catalisadores. Os clorofluorometanos tais como $\mathrm{CCIF}_{3}$ e CCI $\mathrm{F}_{2}$ são fontes possíveis para a presença de átomos de cloro na estratosfera. Estas substâncias, usadas em refrigeração e em aerosóis, são quimicamente inertes mas são decompostas pela radiação ultravioleta de alta energia (185-227 nm) libertando átomos de cloro. Se estes compostos se difundirem da troposfera para a estratosfera eles serão aí decompostos e catalisarão a decomposição do ozono. Pouco se sabe ainda sobre os pormenores da destruição do ozono na estratosfera. Os cálculos teóricos realizados conduzem a resultados divergentes devido às incertezas dos modelos usados. A fotoquímica dos óxidos de azoto e de cloro ainda está insuficientemente conhecida e, por outro lado, existem poucos dados sobre as concentrações relativas na estratosfera.

\section{$O$ azoto}

$\mathrm{O}$ azoto foi descoberto em 1772 pelo químico e botânico escocês Daniel Rutherford. Na sua forma molecular, $\mathrm{N}_{2}$, é o principal constituinte da atmosfera ( $78 \%$ do volume) pelo que mais de três quartos do ar que aspiramos é azoto. A sua origem foi, tal como para os outros constituintes da atmosfera à excepção do oxigénio, o processo de desgasificação das rochas que ocorreu em fases primitivas da história do nosso planeta. Mas como as suas moléculas são demasiado pesadas (e portanto lentas) para se terem escapado à atracção da Terra e, por outro lado, são pouco reactivas para se combinarem em grande escala com outras substâncias, o azoto permaneceu na atmosfera e tornou-se o seu constituinte maioritário.

Tal como o oxigénio, o azoto forma moléculas diatómicas; mas na molécula de $\mathrm{N}_{2}$ os átomos estão ligados por uma ligação tripla $\mathrm{N} \equiv \mathrm{N}$, que é das ligações mais fortes que se conhecem. Isto faz com que a molécula de $\mathrm{N}_{2}$ possa sobreviver por exemplo a colisões fortes com outras moléculas, colisões estas que no caso do oxigénio teriam conduzido a uma reacção química. Esta relativa falta de reactividade do azoto faz com que ele funcione na atmosfera como um diluente do perigoso oxigénio. Se não houvesse azoto na atmosfera, já há muito tempo que um relâmpago teria queimado toda a vegetação da Terra. Porém, a inércia do azoto não deve ser confundida com a inércia dos gases raros. A inércia destes resulta da configuração electrónica dos seus átomos individuais que não lhes confere a tendência para se conbinarem com outros átomos. No caso do azoto, a inércia é uma propriedade da molécula e não dos átomos e resulta da dificuldade em quebrar a ligação tripla. Uma vez esta quebrada, no entanto, o azoto é muito reactivo e forma inúmeros 
compostos. A utilização mais corrente do azoto molecular deriva da sua fraca reactividade e da sua grande acessibilidade. É usado na indústria electrónica e nos laboratórios de química como atmosfera protectora quando se controem componentes ou se realizam reacções que seriam negativamente afectadas pelo oxigénio atmosférico.

Os compostos de azoto são muito usados como fertilizantes e como explosivos. Antes da 1. a Guerra Mundial a principal fonte comercial de produtos azotados eram os depósitos de nitratos (nitrato do Chile, $\mathrm{NaNO}_{3}$, por exemplo). Foi então que o químico alemão Fritz Haber descobriu as condições nas quais o azoto era obrigado a reagir com o hidrogénio para dar amoníaco, $\mathrm{NH}_{3}$ :

$\mathrm{N}_{2}(\mathrm{~g})+3 \mathrm{H}_{2}(\mathrm{~g}) \underset{\text { catalisiador de } \mathrm{Fe}}{\stackrel{\text { Te pelevadas }}{\Rightarrow}} 2 \mathrm{NH}_{3}(\mathrm{~g})$

São condições de elevada temperatura $\left(400-600^{\circ} \mathrm{C}\right)$ e de elevada pressão (200-400 atm) e a reacção é acelerada por um catalisador de ferro. Haber recebeu em 1918 o prémio Nobel da Química pelo seu trabalho sobre a síntese do amoníaco.

O azoto na forma de compostos é um importante constituinte dos seres vivos. A maioria das moléculas das células contém átomos de azoto; é o caso das proteínas e dos ácidos nucleicos. O azoto é essencial para o crescimento das plantas e das sementes. Alguns organismos têm a capacidade de usar directamente o azoto atmosférico para produzir compostos azotados. É o caso das bactérias fixadoras de azoto muitas das quais se desenvolvem em nodosidades das raízes de plantas leguminosas (feijão, ervilhas, trevo, etc.). $\mathrm{O}$ agente responsável pela fixação do azoto (transformação do $\mathrm{N}_{2}$ em compostos) nestes organismos é um enzima chamado nitrogenase que é constituído por duas moléculas de proteínas. Os químicos industriais estão fortemente interessado em conhecer o mecanismo de acção da nitrogenase dado que, se ele pudesse ser imitado, forneceria um meio simples de retirar azoto da atmosfera e de o redistribuir como fertilizante.

Outra fonte de compostos de azoto são as trovoadas. As descargas levam o $\mathrm{N}_{2}$ a reagir com $\mathrm{O}_{2}$ para formar óxido nítrico que é arrastado para o solo pelas chuvas.

\section{O dióxido de carbono}

O dióxido de carbono foi um gás abundantemente libertado na fase de desgasificação da Terra. No entanto, teve um destino muito diferente do do azoto porque foi na sua maioria incorporado nas rochas carbonatadas (calcário e grés). Actualmente $\mathrm{o} \mathrm{C}_{2}$ é apenas o quarto constituinte da atmosfera terrestre (seca) mas é o constituinte mais abundante das atmosferas de Vénus e Marte. Na Terra primitiva as fortes precipitações que deram origem à formação dos oceanos arrastaram consigo a maior parte do dióxido de carbono, que é bastante solúvel na água. Em Vénus essa forte precipitação nunca ocorreu devido à elevada temperatura da superfície e, em Marte, ela foi insuficiente pelo que nesses planetas o $\mathrm{CO}_{2}$ ficou na atmosfera. Cálculos obviamente muito aproximados mostram que a soma da masa de $\mathrm{CO}_{2}$ presente nas rochas com o $\mathrm{CO}_{2}$ dissolvido nos oceanos e o presente na atmosfera terrestre dá uma quantidade aproximadamente equivalente à que existe na atmosfera de Vénus.

$\mathrm{O}$ dióxido de carbono é o gás que expiramos porque ele é o produto final do consumo das substâncias orgânicas que ingerimos como alimentos. A combustão de um composto orgânico (e aqui inclui-se a combustão extremamente lenta e sofisticada que ocorre nas células a que chamamos «metabolismon) realiza-se com produção de $\mathrm{CO}_{2}$, que constitui o termo do processo, por vezes complexo, de combinação do carbono com o oxigénio. Por isso se diz que o dióxido de carbono é a forma morta do carbono. No entanto o $\mathrm{CO}_{2}$ não é inerte, dado que as plantas verdes utilizam a energia da luz solar para o retirar da atmosfera e o combinar com o hidrogénio (obtido a partir da água) para produzir os seus hidratos de carbono no processo conhecido por fotossíntese. A energia libertada na produção de $\mathrm{CO}_{2}$ num músculo serve para levantar um peso. No cérebro serve para formular uma ideia. O dióxido de carbono é também o produto final do consumo dos hidratos de carbono durante os processos de fermentação e é por isso que o encontramos na espuma da cerveja e nas bolhas do champagne (ele liberta-se do líquido quando se abre a garrafa e a pressão diminui). $\mathrm{Na}$ água o dióxido de carbono, juntamente com aromas diversos, é usado para fabricar bebidas variadas. Ao dissolver-se na água ele forma um ácido fraco, o ácido carbónico, que pica na língua e actua como bactericida suave. Também se pensa que o ácido carbónico acelera o fluxo do estômago para o intestino (alka seltzer) o que explica provavelmente o efeito enebriante rápido do champagne.

O dióxido de carbono na atmosfera tem um papel importante como regulador térmico, como moderador da temperatura superficial. Esse papel também é desempenhado pelas nuvens. A superfície superior das nuvens é fortemente reflectora, isto é, reflecte para o espaço grande parte da radiação solar incidente (cerca de $90 \%$ ). Isto poderia levar a um arrefecimento da superfície se as nuvens não desempenhassem por outro lado um papel oposto. Com efeito, a luz solar que atinge a superfície da Terra aquece-a e esta energia calorífica é radiada pela Terra sob a forma de radição infra-vermelha. As nuvens absorvem esta radiação não a deixando escapar e re-irradiam-na em parte para a Terra constituindo assim uma espécie de «armadilha» térmica. A energia assim retida aquece a atmosfera num processo designado por efeito de estufa. $\mathrm{O}$ dióxido de carbono atmosférico também contribui para o efeito de estufa porque as suas moléculas absorvem fortemente no infravermelho mas são transparentes (não absorvem) à radiação solar que atinge a superfície da Terra.

$\mathrm{O}$ teor em $\mathrm{CO}_{2}$ da atmosfera tem aumentado nas últimas décadas devido, segundo se pensa, à combustão dos combustíveis fósseis. Desde 1890, data em que se iniciou um consumo significativo destes combustíveis, a concentração de $\mathrm{CO}_{2}$ terá aumentado de $290 \mathrm{ppm}$ para $330 \mathrm{ppm}$ e a taxa de aumento tem crescido progressivamente. Cálculos climatológicos prevêem um aumento de $3{ }^{\circ} \mathrm{C}$ na temperatura à superfície do planeta se a concentração de $\mathrm{CO}_{2}$ duplicasse. É no entanto necessário encarar com reserva estes resultados, dado que os modelos em que se baseiam dependem de inúmeras variáveis, o que torna difícil a previsão. 


\section{Constituintes menores e poluição atmosférica}

Alguns constituintes atmosféricos estão presentes apenas em concentrações muito baixas. É o caso, entre outros, do monóxido de carbono, do dióxido de enxofre, do óxido nítrico. Por exemplo, as erupções vulcânicas atiram para a atmosfera dióxido de enxofre, $\mathrm{SO}_{2}$, e monóxido de carbono, CO. Os incêndios florestais fornecem monóxido de carbono e outros compostos. As decomposições bacteriológicas dão origem a metano, amoníaco e óxido nítrico. Por outro lado, alguns microrganimos removem da atmosfera alguns destes constituintes, como é o caso do monóxido de carbono que é consumido por determinados fungos que vivem no solo onde crescem plantas gramíneas.

Estes constituintes menores tornam-se poluentes quando são produzidos, por fontes naturais ou "civilizadas», a uma velocidade maior do que aquela a que são consumidos pelos processos naturais ou quando, devido a determinadas condições meteorológicas, se concentram numa dada região. $\mathrm{O}$ monóxido de carbono é um poluente nas áreas urbanas que é produzido pelos escapes dos automóveis e que, por isso, está presente em concentração elevada nas horas de ponta. É um gás tóxico porque se liga fortemente à hemoglobina dos glóbulos vermelhos dando origem à carboxi-hemoglobina:

\section{Hemoglobina $+\mathrm{CO} \Leftrightarrow$ carboxi-hemoglobina}

inibindo assim a sua função de transportador do oxigénio dos pulmões para as células do corpo. Numa situação normal o sangue vai aos pulmões buscar o oxigénio que, ligando-se à hemoglobina, é depois transportado para as diferentes partes do organismo sob a forma de oxi-hemoglobina

\section{Hemoglobina $+\mathrm{O}_{2} \Leftrightarrow$ oxi-hemoglobina}

O monóxido de carbono liga-se mais fortemente à hemoglobina que o oxigénio impedindo assim a sua função.

Outro problema de poluição é o chamado smog fotoquímico que acontece por vezes nas grandes cidades. Trata-se de um nevoeiro irritante provocado por processos fotoquímicos (induzidos pela radiação) que ocorrem quando o ar contém determinados poluentes nomeadamente óxidos de azoto, $\mathrm{NO}$ e $\mathrm{NO}_{2}$, e hidrocarbonetos que são produzidos pelos escapes dos automóveis. Os primeiros formam-se a partir do $\mathrm{N}_{2}$ e do $\mathrm{O}_{2}$ atmosféricos por aquecimento no sistema de escape os segundos resultam da combustão incompleta da gasolina nos motores. O dióxido de azoto é um gás de cor alaranjada forte que, com as partículas de poeira do ar, é responsável pela cor do smog. Os processos fotoquímicos que aí ocorrem conduzem à formação de moléculas diversas como o peróxido de hidrogénio, $\mathrm{H}_{2} \mathrm{O}_{2}$, e fragmentos desta molécula como $\mathrm{HO}_{2} \mathrm{e}$ HO. O carácter muito reactivo destas espécies leva-as a atacar os hidrocarbonetos, dando origem a outros compostos como o nitrato de peroxi-acetilo (ou PAN), $\mathrm{C}_{2} \mathrm{H}_{3} \mathrm{O}_{5} \mathrm{~N}$, cuja estrutura é<smiles>CC(=O)OO[N+](=O)[O-]</smiles>

Este composto é um derivado do peróxido de hidrogénio em que um dos hidrogénios foi substituído pelo grupo $\mathrm{CH}_{3} \mathrm{CO}$ e outro por $-\mathrm{NO}_{2}$. Trata-se de um gás lacrimogénio que é largamente responsável pelos prejuízos que o smog causa à vegetação (combustão parcial devido ao seu forte carácter oxidante). Para combater o smog adapta-se ao sistema de escape dos automóveis um dispositivo, chamado conversor catalítico, que transforma os óxidos de azoto em azoto molecular e os hidrocarbonetos em dióxido de carbono e vapor de água. Para tal usam-se catalisadores como o óxido de platina ou o óxido de cobre (II). Os automóveis que dispõem de um conversor catalítico não podem consumir gasolina com chumbo porque a combustão desta produz compostos de chumbo voláteis que tornam o catalisador inactivo.

Outro problema de poluição são as chamadas chuvas ácidas. Um dos seus componentes é o ácido nítrico que se forma quando o dióxido de azoto se dissolve na água das chuvas. Outro constituinte das chuvas ácidas é o ácido sulfúrico que se forma quando o dióxido de enxofre, $\mathrm{SO}_{2}$, se transforma em trióxido de enxofre, $\mathrm{SO}_{3}$, nas gotas de água transportadas pelo ar. O dióxido de enxofre é um gás incolor, tóxico, com cheiro sufocante, que se forma durante a combustão ao ar do enxofre ou de substâncias cujas moléculas contêm átomos de enxofre. É também expelido pelos vulcões e produzido em instalações fabris para extracção de metais a partir de minérios de ferro ou cobre (pirite, $\mathrm{FeS}_{2}$, ou sulfureto de cobre, $\mathrm{CuS}$ ). O dióxido de enxofre é usado como conservante em alimentos e bebidas devido à sua facilidade em combinarse com o oxigénio, oxigénio este que de outra forma atacaria o artigo a conservar. As moléculas responsáveis pela cor e pelo aroma dos frutos secos e dos sumos de fruta sobrevivem melhor na presença de $\mathrm{SO}_{2}$. Esta substância também é usada para impedir a oxidação dos vinhos. O dióxido de enxofre é produzido em grandes quantidades na indústria do ácido sulfúrico (combustão do enxofre). Uma vez formado, o $\mathrm{SO}_{2}$ é levado a reagir com um átomo de oxigénio, com a ajuda de um catalisador, para formar o trióxido de enxofre, $\mathrm{SO}_{3}$, que reage rapidamente com a água para dar ácido sulfúrico. A transformação do dióxido em trióxido também ocorre sem catalisador mas mais lentamente; é nessas condições que se forma o ácido sulfúrico das chuvas ácidas. 
instrumentor de laboratório e eientíficos lda

LISBOA - PORTO PONTA DELGADA

$A A-I C P-F T-I R-U V-V I S-G C-H P L C$

TERMO ANÁLISE - BIOQUIMICA - UV - NIR

PERKIN ELMER

ESPECTROMETRIA DE MASSA

finnigan

mat

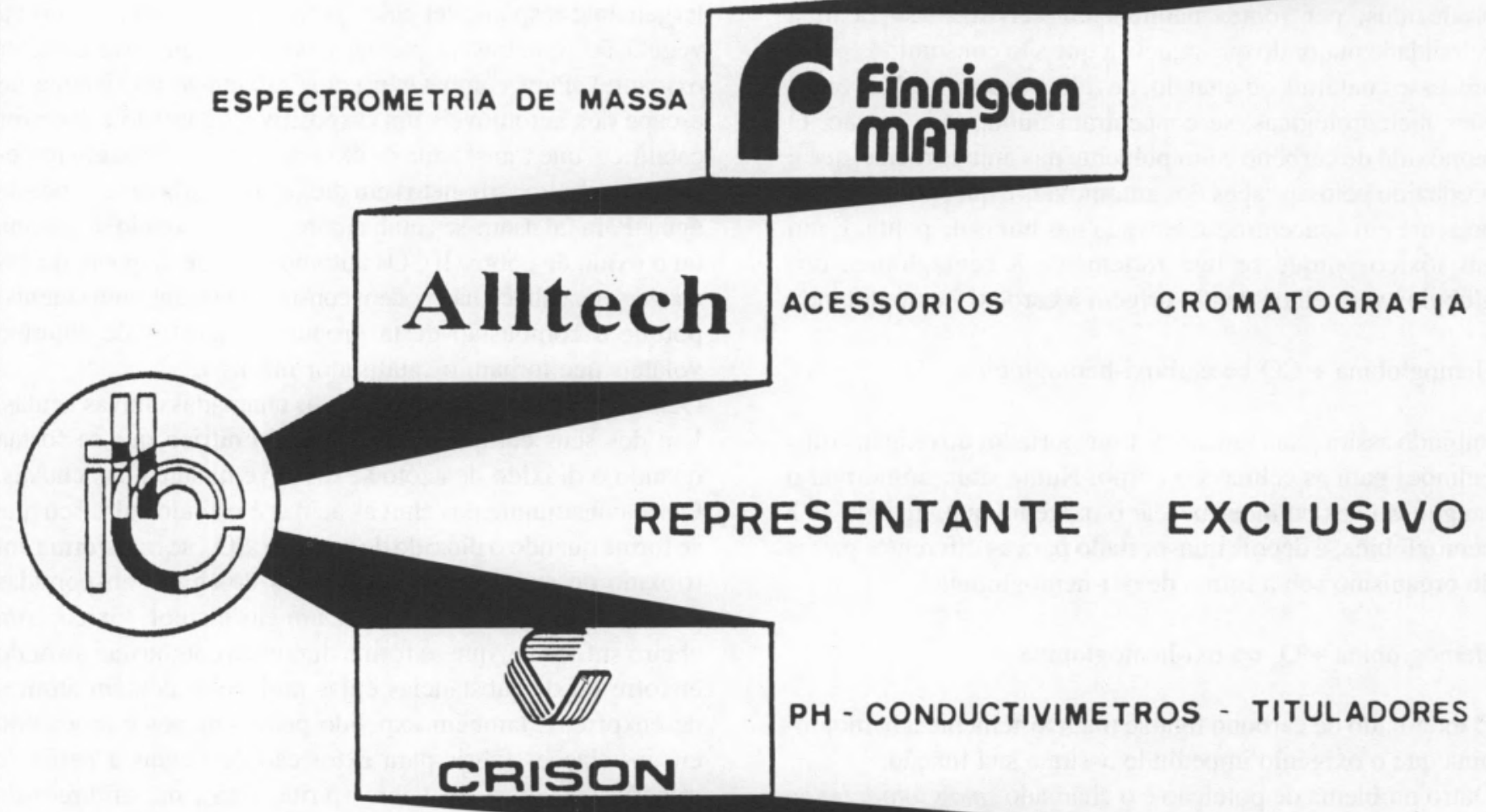

BALANÇAS ELECTRONICAS

\section{COBOS

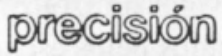

